\title{
ПСИХОЛОШКИ ОСВРТ КОН МОБИНГОТ: ПОЈАВА, ФАКТОРИ И МЕРЕЊЕ
}

\section{Панајотис Цакирпалоглу}

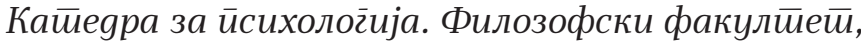
Универзииеиеи Палацки, Оломоуи, Чешка Рейублика ${ }^{1}$

\section{Симона Добешова-Цакирпалоглу}

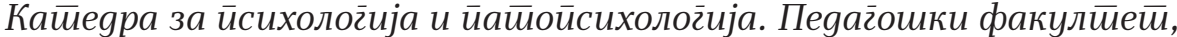

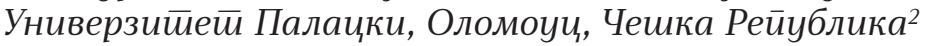

\section{Јан Шмахај}

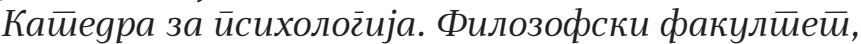
Универзииеей Палацки, Оломоуи, Чешка Ррейублика

\section{Мартин Зиелина}

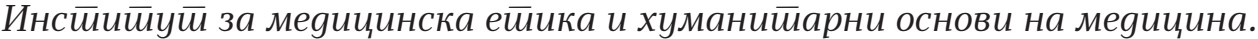

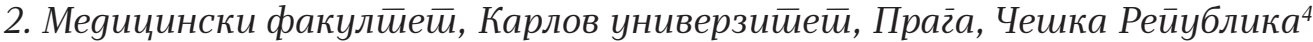

\section{Кратка содржина}

Психолошкиот интерес за мобингот кој трае повеќе од две децении укажува на тоа дека постојат различни проценки за стапката на распространетост на оваа појава, односно дека ваквите разлики не се должат само на методолошки причини туку вклучуваат редица персонални, организациски и културни специфичности. Она, околу што емпириските студии се согласуваат е дека со долготрајниот мобинг редовно се присутни психички и други компликации кај виктимизираниот работник. Целта на оваа статија е стручен приказ на психолошките одредби и чинители на мобингот со осврт врз методолошките прашања поврзани со мерење на виктимизацијата во работен колектив. Посебен акцент се става врз проблемот на успешно диференцирање различни видови мобинг со примена на бихевиорални и субјективни индикатори на виктимизацијата. За мерење на мобингот беше користена чешката верзија на ревидираниот Прашалник за негативно однесување на работно место (NAQ - R). Резултатите од истражувањето спроведено врз 7.103 вработени во државни, приватни и невладини колективи во Чешка Република покажа дека општата проценка на мобирани лица се движи помеѓу 14,84 \% и 24,78 \%. Подлабок увид во структурата на мобирани работници нудат критериумите минимален број бихевиорални индикатори и перцепцирана виктимизација, при што резултатите од 7.103 испитани вработени се диференцираат на 81,75 \% немобирани и 18,28 \% виктимизирани поединци. Со вкрстување на двата критериуми беше утврдена најкритичната група од 7,79 \% лица со свест за сопствената виктимизација и емпириска потврда за мобинг на работното место.

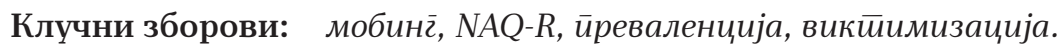

\footnotetext{
panajotis.cakirpaloglu@upol.cz simona.dobesova@upol.cz jan.smahaj@upol.cz

martin.zielina@lfmotol.cuni.cz
} 


\section{Вовед}

Интерперсоналните конфликти се нормална појава во сите хумани ситуации вклучувајќи го и работниот колектив. Иако станува збор за природна појава, некои конфликти на работното место посебно негативно влијаат, како врз непосредно инволвираните актери, така и врз останатите сведоци на немилиот настан (Paull, Omari, \& Standen, 2012). Насилството на работно место алтернативно се означува со поимот мобинг. Долготрајниот мобинг трајно негативно влијае врз вработениот, колективот, но и пошироко, врз општеството (Camerino, Estry-Behar, Conway, Heijden, \& Hasselhorn, 2008). Станува збор за релативно стара појава која за прв пат во 80-тите години на минатиот век стана предмет на доследна научна анализа, најнапред во Скандинавија, а подоцна и во поразвиените земји од Западна Европа. Паралелно, сѐ повеќе стануваше јасна врската помеѓу мобингот и проблемите во јавното здравство (Flannery, 1996; Leather, Lawrence, Beale, Cox, \& Dickson, 1998). Инаку, мобингот е диверзифициран феномен со разновидна појавност, најчесто како вербален или физички напад, агресија, застрашување, закана итн. (Camerino et al., 2008). Покрај зголемена анксиозност, депресивност, суицидност и други проблеми, со мобингот се поврзани сериозни здравствени, економски и социјални последици. Истражувањата покажаа дека мобингот ги зголемува трошоците за лекување на жртвите, нивната флуктуација односно предвремено одење во пензија, ја намалува продуктивноста на трудот, имиџот на работната организација и слично (Hoel, Sparks, \& Cooper, 2001). Според некои проценки, американските фирми поради мобинг загубиле 23,8 милијарди долари кои биле вложени за лекување и боледување или компензации поради смалена продуктивност на жртвите (Decoster, Camps, Stouten, Vandevyvere, \& Tripp, 2013). Слични наоди изнесува Институтот за работна медицина на Германија, според кои мобингот е причина за 20 \% самоубиства и финансиска загуба од 50 милијарди евра (Giaccone, Nunzio, Fromm, \& Vargas 2015).

Оваа статија има за цел да ги прикаже психолошките дефиниции со методолошки потенцијал за валидно мерење на мобингот, да ги објасни причините за различни емпириски наоди проценки на мобинг и да предложи модел за релевантно психолошко откривање на различни видови мобинг.

\section{Психолошка оgреgба на мобинг̄}

Мобингот за прв пат е опишан во 1984 година од страна на шведскиот професор Heinz Leymann (1996) како „суптилно манифестирање агресија на работно место врз определен работник, при што работникот секојдневно, во 
тек на неколку месеци се соочува со непријателство од страна на еден или на повеќе вработени. Жртвата на мобингот чувствува немоќ и страв од исклучување од колективот“. Во тој контекст Leymann зборува за пет стратегии на мобинг: спречување изразување сопствено мислење и комуницирање, оневозможување социјален контакт, атак врз репутацијата на жртвата, напади врз нејзиниот професионален и персонален живот и на крајот, општо загрозување на нејзиното здравје. Долготрајниот мобинг е редовно придружуван со страв, понижување и следење на жртвата, наметнување бесмислени и тешки задачи, недоверба, озборување итн. (Parzefall \& Salin, 2010).

Во литературата исто така преовладува определбата на Einarsen и сор. дека мобингот постои како „малтретирање, навреди и социјална изолација на вработениот, односно манифестирање негативен став кон неговиот труд. Ваквата негативна пракса прераснува во мобинг доколку се случува редовно (еднаш неделно) и трае долго (шест месеци). Со ескалирање на процесот жртвата станува инфериорна и цел на нови напади“ (Einarsen, Hoel, Zapf, \& Cooper, 2011, s. 22). За поегзактно мерење на мобингот Leymann (1996) поаѓа од најмалку една негативна постапка со која неделно, во текот на шест месеци се соочува жртвата на мобинг, додека Mikkelsen и Einarsen (2001) во спомнатиот временски интервал и распон на мерење предлагаат построг критериум од најмалку два евидентирани негативни акти.

Дефиницијата на Einarsen и cop. (Einarsen et al., 2011) акцентира четири типични манифестации на мобинг: непожелно однесување, повторување, редовност и нерамноправна дистрибуција на моќ. Првиот аспект постулира дека жртвата на работно место е постојано изложена на директни или индиректни постапки кои се морално и статутарно неприфатливи (озборување, потсмевање, криење информации од значење за работниот процес, критика на начинот и резултатите на активноста, претерана контрола итн.). Следниот аспект на мобингот е повторување на негативните постапки. Мобингот не е изолиран инцидент, туку непријатност која се повторува, трае долго и е насочена против конкретен вработен (Einarsen, Raknes, \& Matthiesen, 1994). Некои вработени трпат мобинг во тек на целата работна кариера (Lawoko, Soares, \& Nolan, 2004). Трет аспект е долготрајност на несаканото однесување кое најчесто се определува помеѓу шест (Leon-Perez, Notelaers, Arenas, Munduate, \& Medina, 2013) и дванаесет месеци (Niedhammer, Chastang, \& David, 2008). Ваквата проценка има емпириска и искуствена заднина. Nielsen, Glasø и Einarsen (2016) во метаанализа на 36 студии, односно 13.869 вработени, утврдиле дека долготрајниот мобинг е следен со невротичност и депресија. Според Sourander и сор. (2009), долготраен мобинг го зголемува ризикот за развој на психијатриски проблеми. Жртвата 
на мобинг неповратно губи самодоверба, работна мотивација и подготвеност да истрае на работното место (Giorgi, Leon-Perez, \& Arenas, 2015; Einarsen \& Nielsen, 2015). На крајот, мобингот е поврзан со перципирана нееднаквост на моќ помеѓу агресорот и жртвата. (Leymann, 1996). Ваквата асиметријата е производ на формалната распределба на позиции и улоги во организацијата, но има и неформално потекло (лични контакти, социјални и комуникациски вештини на одделните актери во колективот и слично) (Cakirpaloglu, Šmahaj, Dobešová Cakirpaloglu, \& Zielina 2016). Нееднаквата моќ честопати е одраз на социјална, физичка, економска или психичка зависност на жртвата (Einarsen, Hoel, Zapf, \& Cooper, 2003). Како значаен динамички момент на мобингот се истакнува свеста на агресорот за недостатоците на жртвата што успешно го користи при иницирање и ескалација на конфликти (Einarsen, 1999).

\section{Чиниеиели на мобинг̄}

Од многуте потенцијални причини на конфликти на работно место со изгледи за развој на мобинг се издвојуваат следните фактори од највисок ризик: индивидуални, организациски, општествени и културни. (Hogh \& Viitasara, 2005; Camerino et al. 2008; Cakirpaloglu et al. 2016).

Кај индивидуалните премиси на мобинг предничат ниската возраст и недостигот на работно искуство на работникот (Lawoko et al., 2004; Camerino et al., 2008). Врската помеѓу полот на вработениот и мобингот не е доволно јасна. Некои истражувања истакнуваат загрозеност кај мажите, други како жртви ги откриваат жените (Lawoko et al. 2004; Camerino et al., 2008; Ortega, Høgh, Pejtersen, \& Olsen, 2009). Следни фактори на ризик се ниската самодоверба (Harvey \& Keashley, 2003), недостигот на емпатија, импулсивноста како и агресивноста. Според некои истражувања од агресивни деца најчесто израснуваат хостилни работници. (Chappell \& Di Martino, 2006). Инаку, жртвите на мобинг се социјално фобични, загрижени, недоверливи, субмисивни и вулнерабилни (Glasø, Nielsen, \& Einarsen, 2009). Со долготраен мобинг редовно се намалува психичката кондиција на жртвата, односно доаѓ до зголемување на фрустрираноста, гневот, стравот, анксиозноста и нетолеранција кон стресот. (Gerberich et al., 2004) Клиничката слика на долготрајно мобираниот покажува знаци типични за посттрауматски стрес (PTSD) (Kreiner, Sulyok, \& Rothenhäusler, 2008; Hogh, Borg, \& Mikkelsen, 2003; Hogh \& Viitasara, 2005). Мобингот предизвикува премор кај жртвата (Hogh et al., 2003) и честа флуктуација од колективот (Camerino et al., 2008). Некои личности се предиспонирани да станат жртви на мобинг заради нивната иницијална нетолерантност или анксиозност (Glasø, 
Matthiesen, Nielsen, \& Einarsen, 2007). Од друга страна, O’Connel и Williams (2002) сметаат дека мобингот повеќе се должи на негативните фактори кои постојат во работниот колектив, а помалку на цртите и предиспозициите на вработениот.

Меѓу организациските ризици за мобинг се истакнуваат работењето со јавност (на пр. здравствени служби), односно дејности поврзани со меѓучовечка комуникација (Hogh et al. 2003; Chappell \& Di Martino, 2006). Од останатите ризични фактори предничат работата во ноќни смени, задачите со кратки рокови, синдромот на професионално согорување (burnout), неквалитетниот тим, долготрајното физичко и психичко напрегање, ригорозната контрола итн. (Estryn-Behar, Van Der Heijden, Camerino, Fry, Le Nezet, Conway, \& Hasselhorn, 2008). Не помалку значајни предуслови за појава на мобинг се стресот, интензивното темпо на работење, меѓучовечките конфликти, лошата организација на работниот процес итн. (Hogh \& Viitasara, 2005; Camerino et al., 2008).

Врз појавата на мобинг влијаат и општествените фактори. Тука спаѓаат слабата поддршка од страна на ресорните органи задолжени за унапредување на производството и хуманизација на работните односи, но и од негрижата на пошироката заедница за безбедност на трудот (Leather, Claire, Beale, Cox, \& Dickson, 1998; Spector, Coulter, Stockwell, \& Matz., 2007). Мобингот најчесто се јавува при недоволна едукација и обука на вработените како да се справат со насилството на работа како и од негрижата од страна на работната организација да развива способности кај вработените за слободна комуникација (Duxbury, \& Whittington, 2005). Мобингот е посебно зачестен при непостоење легислативни норми и соодветни санкции за негативните појави при работењето (Chappell \& Di Martino, 2006; European Agency, 2010).

Во најново време психолошката експликација на мобингот се потпира врз концептот на Hofstede за постоење универзални вредности. Hofstede постулирал дека универзалните вредности учествуваат во создавање специфичен менталитет кај членовите на дадена култура кој натаму ги моделира односите и климата во работниот колектив. Оваа аксиолошка теорија спомнува шест дихотомни вредности: разлики во моќ (близина - оддалеченост), маскулинизам - феминизам, индивидуализам - колективизам, краткорочна ориентација - долгорочна ориентација, избегнување неизвесност - рискантност и склоност кон задоволства - воздржаност (Hofstede, 1984). Односот помеѓу културата, работната организација и мобингот е заснован врз вредносна матрица која ги опфаќа првите три вредносни димензии (Hofstede \& Hofstede, 2001).

Димензијата близина - оддалеченост од моќ е значаен предиктор на мобингот. Така во земји со демократска традиција, на пример во Скандинавија или 
во Австралија вработените се почувствителни на нерамномерно распределување на моќта. Оттука, со вредноста близина на моќ оди ниска толеранција на мобинг. Наспроти тоа, во Сингапур моќта е концентрирана во рацете на мал број богати луѓе и политичари и оттука има пониска перцепција на мобинг меѓу вработените (Loh, Restubog, \& Zagenczyk, 2010).

Димензијата маскулинизам - феминизам е поврзана со патријархалната култура и воспитување. Феминизмот доминира во Шведска или Норвешка каде воедно моќта е рамномерно распределена, постојат развиена социјална чувствителност и просоцијални стремежи. Феминистичката идентификација не толерира непочитување на просоцијалните принципи, вклучувајќи го и мобингот (Lutgen-Sandvik, Tracy, \& Alberts, 2007). Маскулините вредности се доминантни во САД и во Велика Британија каде што мобингот претставува сериозен општествен проблем (Zapf, Einarsen, Hoel, \& Vartia, 2003).

Димензијата индивидуализам - колективизам е поврзан со религиозните премиси на дадената култура. Индивидуализмот редовно постои во протестантските средини каде како вредности доминираат трудот, профитот, самооткажувањето, натпреварот, гордоста заради успех, но и завист, агресија при неуспех и слично. Овие вредности се карактеристични протестантските земји, на пр. САД или Велика Британија со голема преваленција на мобинг. Наспроти тоа, колективизмот во Скандинавија ги моделира односите во работниот колектив, го намалува просторот за конфликти и за мобинг како нивен најрадикален израз. (Lutgen - Sandvik et al., 2007).

\section{Мерни инструменти}

Психологијата нуди теориска рамка за научна експликација на мобингот и развива методи и постапки за егзактно мерење, превенција и интервенција на оваа негативна појава. Со оглед на ограничениот простор, во продолжение ќе биде прикажан психолошки инструмент за утврдување мобинг како и постапка за препознавање на неговите различни појавни облици.

Ревидираниот Прашалник на негативни акти NAQ - R (Negative Act Questionnaire - Revised) од Einarsen и Raknes (1997) содржи 23 ајтеми (слика бр. 1). Првите 22 ајтеми се бихевиорални ставки и во ниедна не е содржан поимот мобинг. Изборот на одговор е разложен на петостепена скала (1. никогаш, 2. понекогаш, 3. месечно, 4. неделно, 5. секојдневно) со што се регистрира дали и колку често во последните шест месеци испитаникот бил изложен на негативни ситуации на работното место. Последниот 23. ајтем од прашалникот е самооценувачки и служи за откривање колку (никојпат, ретко, понекојпат, неколку 
пати неделно, секојдневно) испитаникот се поистоветува со претставата дека е жртва на мобинг. За евоцирање таква претстава пред прашањето е наведена дефиницијата: „Дали некојпат ве шиканирале на работа? Под шикана подразбираме ситуација во која едно или повеќе лица забележуваат дека во подолг временски период се изложени на негативно влијание од страна на едно или на повеќе други лица; загрозената личност има тешкотии да се одбрани од таквото однесување. Ваквиот осамен инцидент не се смета за шикана.“

Методата NAQ - R е стандардизирана во бројни земји. Нејзините солидни психометриски вредности се потврдени во независни истражувања и оттука NAQ - R спаѓa во групата најрелијабилни инструменти за емпириско испитување мобинг (Einarsen, Hoel, Zapf, \& Cooper (Eds.), 2020). Психометриското истражување на NAQ - R во Чешка Република (2016 г.) исто така ја потврди високата релијабилност (Cronbach $\alpha=0,94$ ) и валидност (Pearson $\mathrm{r}=-0.46$ (well-being); $\mathrm{r}$ $=+0,49$ (депресивност); $\mathrm{r}=+$ 0,46 (анксиозност) на чешкиот превод на методата (Cakirpaloglu, Šmahaj, Dobešová Cakirpaloglu, \& Zielina, 2017).

\section{Резултати}

Комбинираното теренско и онлајн истражување беше спроведено во 2016 година врз 7.103 вработени од државен, приватен и невладин сектор. Резултатите укажаа на постоење мобинг во опсег помеѓ 14,84 \% и 24,78 \%. Процентуалните граници на наведената предикција зависеа од примената на построг (најмалку два негативни акти во текот на една седмица за последни 6 месеци) или поблаг (еден негативен акт во текот на една седмица за последни 6 месеци) критериум за проценка на мобинг. Вработените мажи од приватниот сектор беа најчесто изложени на мобинг, додека кај жените мобингот најчесто се јавувал во државните институции. Статистичкиот Т - тест укажа дека мобингот е хетерогена појава. Кај мажите мобингот е поврзан со добивање подредени работни задолженија (под нивната квалификација или компетенција), вршење задачи во екстремно кратки рокови, закани (прикриени или отворени) на работно место итн. Мобингот кај жени најчесто се манифестира преку игнорирање на личноста на жртвата, со отворено или скриено непријателство од страна на вработените и слично. Резултатите исто така укажаа на врска помеѓу мобинг и регионалната стапка на невработеност. Најнизок мобинг бил регистриран во Прага и во оние региони во Чешка каде традиционално постои ниска невработеност (околу 2,2 \%), додека највисока стапка на мобинг била утврдена во Северна Моравија (Острава) каде невработеноста од 6,9 \% е значително повисока од државниот просек (3,5%). 
Натаму, со комбинирање различни критериуми за проценка (поблаг или построг) и начини на мерење мобинг (бихевиорален или самооценувачки) можно е посуптилно навлегување во проблемот на виктимизираните лица. Ваквата постапка првично беше најавена од Nielsen и сор. (2009) и Einarsen et al. (2011). Впрочем, истражувањата покажаа дека NAQ - R успешно ги диференцира немобираните од мобираните вработени лица. Анализата на емпириските резултати од истражувањето во Чешка покажа дека индикаторите на методата NAQ - R содржат премиси со кои е можно издвојување различни типови жртви на мобинг (Cakirpaloglu, et al., 2016), а со вкрстување на два критериуми и два начини на мерење мобинг се добива постапка за статистичко диференцирање на сегментот потенцијално виктимизирани лица. Во конкретниот случај, од 7.103 тестирани лица издвоени беа четири категории (квадранти) вработени, чии специфичности во однос на мобингот ги презентира табелата бр. 1.

\section{Табела 1: Дистрибуција на мобирани според индикатори и перцепција на мобинг}

\begin{tabular}{|c|c|c|}
\hline & \multicolumn{2}{|c|}{ Помалку од два негативни акта Два и повеќе негативни акта } \\
\hline $\begin{array}{ll}\text { Перципирана } & \text { Не } \\
\text { виктимизација } & \end{array}$ & $\begin{array}{l}\text { Квадрант } 1 \\
81,75 \text { \% (N = 5807) } \\
\text { Не чувствува мобинг и нема } \\
\text { знаци на мобинг }\end{array}$ & $\begin{array}{l}\text { Квадрант } 2 \\
7,05 \% \text { (N = 501) } \\
\text { Не чувствува мобинг, но } \\
\text { постојат знаци на мобинг }\end{array}$ \\
\hline Да & $\begin{array}{l}\text { Квадрант } 3 \\
3,41 \text { \% (N = 242) } \\
\text { Чувствува дека е мобиран, но } \\
\text { нема знаци на мобинг }\end{array}$ & $\begin{array}{l}\text { Квадрант } 4 \\
\text { 7,79 \% (N = 553) } \\
\text { Чувствува дека е мобиран и } \\
\text { постојат знаци на мобинг }\end{array}$ \\
\hline
\end{tabular}

Првиот квадрант опфаќа 5.807 (81,75 \%) испитаници кои не се доживуваат како мобирани, а воедно нема емпириски доказ за мобирање. Останатите 1.296 $(18,25$ \%) мобирани испитаници се делат во три различни групи. Првата група (втор квадрант) опфаќа 501 (7,05 \%) лице без перцепција на мобинг, но со индикатори за постоење долготрајна виктимизација. Ваквите поединци субјективно се совпаѓаат со испитаниците од првиот квадрант (немобирани), но со оглед на емпириската евиденција, кај нив постои висок ризик за развој на мобинг. Наспроти овие две категории, третиот и четвртиот квадрант опфаќаат 795 (11,2 \%) вработени кои чувствуваат дека врз нив се спроведува мобинг. Меѓутоа, обете групи се разликуваат во емпириската поддршка на субјективните искуства. Имено, во третиот квадрант 242 (3,41 \%) се лица со чувство на мобирање, но без емпириска евиденција за неговото постоење. Станува збор за т.н. псевдожртви на мобинг. Во последниот, четврти квадрант има 553 (7,79 \%) вработени кои претставуваат потенцијално најзагрозена група мобирани лица, со оглед на постоење субјективно искуство на загрозеност и јасни тестовни индикатори за долготрајна виктимизација. 


\section{Дискусија}

Првична цел на оваа статија е стручен приказ на психолошка дефиниција од која произлегуваат бројни методолошки и истражувачки студии за мобингот. Првата дефиниција на професорот Leymann (1984) операционално ја дополнија Einarsen и сор. (2011) и создадоа концепциска платформа за создавање психолошки инструмент за мерење на мобингот. Врз тие основи изникна Прашалник за негативно однесување на работно место (Negative act questionnaire - NAQ) во чија ревидирана форма (NAQ - R) се вградени мерни индикатори од дефиницијата за мобинг на Einarsen и сор. Обете групи индикатори, бихевиорални и самооценувачки, овозможуваат психолошка проценка на насилство на работното место, воедно и проценка на преваленција (распространетост) на мобинг во општествени и културни рамки. Последново имлицира постоење различни јазични платформи на NAQ - R. Психометриско испитување на релијабилноста и валидноста кај NAQ - R е спроведено во Јапонија, Италија, Грција, Романија, В Британија, САД, Италија, Индија, Шпанија, Тајван, Јужна Кореја, Белгија, Бразил, Естонија, Србија или Чешка и во спомнативе земји методава стана главен психолошки инструмент за индивидуално и општо утврдување мобинг (Einarsen, Hoel, Zapf, \& Cooper, 2020).

Чешката верзија на NAQ - R беше стандардизирана во 2016 година врз емпириски наоди од 7.103 вработени. Наодите за висока релијабилност и валидност на методата беа дополнети со сознанија од факторска анализа. Експлоративната анализа на модифицираниот модел на Einarsen и cop. (2009) ги издвои факторите (F1) мобинг насочен кон работната активност, (F2) мобинг насочен кон личноста на вработениот и (F3) мобинг како физичка закана и заплашување. Овие три фактори објаснуваат 64 \% варијабилност на резултатите. Од друга страна, конфирматорната факторска анализа дополнително ја потврди факторската структура на чешката верзија на методата (Cakirpaloglu et al. 2017). Слични наоди за факторската структура на методата соопштуваат Tsuno и сор. (2010), Charilaos и cop. (2015), Lee, Kim, Shin и Lee (2016) и други.

Следна цел на статијата е објаснување на дискрепантните проценки дека мобингот во Чешка Република е застапен помеѓу 14,84 \% до 24,78 \%. Поаѓајќи од бихевиоралните и самооценувачките индикатори на NAQ-R и можноста за нивна комбинација со строг и благ критериум на проценка можно е добивање различни проценки на мобингот. Благата интерпретација на бихевиоралните индикатори упатува на 24,78 \% мобирани што соодветствува со наодите на Еурофонд од 2015 година, според кои Чешка Република и Австрија со проценет мобинг над 20 \% спаѓаат меѓу најзагрозените европски земји (Giaconne, et al., 
2015). Со строгиот критериум наведената проценка е значително пониска и изнесува 14,84 \% мобирани. Слично, Nielsen и кол. (2010) со примена на строг критериум соопштуваат 12 \% мобинг во скандинавските земји, додека Giorgi и кол. (2011) на ист начин утврдиле 15,2 \% мобинг во Италија. Проценките за мобинг изведени врз самооценување на вработените се значително пониски и изнесуваат 19,82 \% (благ критериум) и 11,19 \% (строг критериум). Субјективна деевалуација на мобингот соопштуваат и странски студии (на пр. Nielsen et al., 2010; Buunk, Franco, Dijkstra, \& Zurriaga, 2016). Според Carter и сор. (2013), Nielsen и сор. (2010) или Agervold (2007) ниските проценки за мобинг изведени од самооценувачки податоци честопати артикулираат одбивање на претставата за немоќна жртва од страна на мобираните работници.

Последна цел на статијата е утврдување можности за релевантна емпириска проценка на мобинг со вкрстување на спомнатите критериуми (строг - благ) и индикатори (бихевиорални - самооценувачки) на методата NAQ-R. Емпириската предност на вкрстената проценка доведува до редукција на грешки при преценување и потценување на виктимизираните работници. Комбинираната постапка во нашето истражување резултираше со проценка од 7,79 \% мобирани кои, со оглед на присуство на индикатори и свест за долготрајна виктимизација на работно место, претставуваат најзагрозена категорија мобирани. Сепак, ваквата постапка за диференцирање не е честа. Комбинираната проценка беше применета во студијата на Nielsen и сор. (2009) при што беа диференцирани 1,6 \% мобирани. Дискрепанцијата во проценките од чешкото и истражувањето на Nielsen и сор. укажува на ограничени можности за споредување на наодите од методата NAQ-R. Впрочем, во Норвешка, Италија, Шпанија, Естонија, Чешка Република и во останатите земји каде бил применет NAQ - R постојат културни, социјални, организациски и редица други специфичности. Натаму, причината на спомнатата дискрепанција може да произлегува од нееднаквата операционализација на мобингот (Leon-Perez, Notelaers, Arenas, Munduate, \& Medina, 2013; Berthelsen, Skogstad, Lau, \& Einarsen, 2011) односно од изборот на благ (Leymann, 1996) или строг (Mikkelsen \& Einarsen, 2001) критериум. Токму отсуството на релевантни информации за избор на критериум и начин на мерење може да резултира со преценување на стапката на мобирани. На пример, студијата Eurofound не наведува врз кои критериум е проектирана проценката за мобирани (Giaconne, et al., 2015). 


\section{Литература}

Agervold, M. (2007). Bullying at work: A discussion of definitions and prevalence, based on an empirical study. Scandinavian Journal Of Psychology, 48(2), 161-172.

Berthelsen, M., Skogstad, A., Lau, B., \& Einarsen, S. (2011). Do they stay or do they go? International Journal of Manpower, 32(2): 178-193.

Buunk, A. P., Franco, S. Dijkstra, P., \& Zurriaga, R. (2016). Mobbing in Schools and Hospitals in Uruguay Prevalence and Relation to Loss of Status. Journal of interpersonal violence, 0886260515325903.

Carter, M. Thompson, N., Crampton, P., et al. BMJ Open 2013; 3.

Cakirpaloglu, P., Šmahaj, J., Cakirpaloglu, S., \& Zielina, M. (2016). Šikana na pracovišti $v$ České republice: teorie, výzkum a praxe. Univerzita Palackého v Olomouci.

Cakirpaloglu, P., Šmahaj, J., Cakirpaloglu, S. D., \& Zielina, M. (2017). Šikana na pracovišti: reliabilita a validita českého překladu revidované verze dotazníku negativních aktů-NAQ-R. Československá Psychologie, 61(6), 546558.

Camerino, D., Estryn-Behar, M., Conway, P. M., van Der, B. I. J. M., \& Hasselhorn, H. M. (2008). Work-related factors and violence among nursing staff in the European NEXT study: a longitudinal cohort study. International journal of nursing studies, 45(1), 35-50.

Chapell, D. \& Di Martino, V.(2006). Violence at work. 3th Edition. Geneva: ILO.

Charilaos, K., Galanakis, M., Chryssa, B.-T., Panagiota, D., George, C. P., \& Christina, D. (2015). Validation of the Negative Acts Questionnaire (NAQ) in a sample of Greek teacher. Psychology, 6, 63-74.

Decoster, S., Camps, J., Stouten, J., Vandevyvere, L. \& Tripp, T. M. (2013).

Standing by Your Organization: The Impact of Organizational Identification and Abusive Supervision on Followers' Perceived Cohesion and Tendency to Gossip. Journal of Business Ethics, 118(3), 623-634.

Duxbury, J., \& Whittington, R. (2005). Causes and management of patient aggression and violence: staff and patient perspectives. Journal of advanced nursing, 50(5), 469-478.

Einarsen, S., Hoel, H., Zapf, D., \& Cooper, C. L. (2011). The concept of bullying and harassment at work: The European tradition. Bullying and harassment in the workplace: Developments in theory, research, and practice, 2, 3-40.

Einarsen, S., Raknes, B. R. I., \& Matthiesen, S. B. (1994). Bullying and harassment at work and their relationships to work environment quality: An 
exploratory study. European journal of work and organizational psychology, 4(4), 381-401.

Einarsen, S., \& Nielsen, M. B. (2015). Workplace bullying as an antecedent of mental health problems: a five-year prospective and representative study. International Archives of Occupational and Environmental Health, 88(2), 131-142.

Einarsen, S., Hoel, H., Zapf, D. \& Cooper, C. L. (2003) The concept of bullying at work. In S. Einarsen (Ed.). Bullyng and emotional abuse in the workplace: International perspectives in research and practice. London: Taylor and Francis, 3-30.

Einarsen, S. (1999). The nature and causes of bullying at work. International journal of manpower, 20(1/2), 16-27.

Einarsen, S. V., Hoel, H., Zapf, D., \& Cooper, C. L. (Eds.). (2020). Bullying and Harassment in the Workplace: Theory, Research and Practice. CRC Press.

Einarsen, S., Hoel, H., \& Notelaers, G. (2009). Measuring exposure to bullying and harassment at work: Validity, factor structure and psychometric properties of the Negative Acts Questionnaire-Revised. Work and Stress, 23(1), 24-44.

Estryn-Behar, M., Van Der Heijden, B., Camerino, D., Fry, C., Le Nezet, O., Conway, P. M., \& Hasselhorn, H. M. (2008). Violence risks in nursingresults from the European 'NEXT' Study. Occupational medicine, 58(2), 107114.

Flannery Jr, R. B. (1996). Violence in the workplace, 1970-1995: A review of the literature. Aggression and Violent Behavior, 1(1), 57-68.

Giaccone, M., Nunzio, D. Fromm, A., Vargas, O. (2015). Violence and harassment in European workplaces: Extent, impacts and policies. Retrie Dublin. Retrieved September 15, 2016, from:

https://www.eurofound.europa.eu/observatories/eurwork/ comparativeinformation/vilence-and-harassment-in-europeanworkplaces-extent-impacts-and\%20policies.

Gerberich, S. G., Church, T. R., McGovern, P. M., Hansen, H. E., Nachreiner, N. M., Geisser, Ms. S., et al. (2004). An epidemiological study of the magnitude and consequences of work related violence: The Minnesota Nurses' Study. Occupational and Environmental Medicine, 61, 495-503.

Giorgi, G., Leon-Perez, J. M., \& Arenas, A. (2015). Are bullying behaviors tolerated in some cultures? Evidence for a curvilinear relationship between workplace bullying and job satisfaction among Italian workers. Journal of Business Ethics, 131(1), 227-237. 
Glasø, L., Nielsen, M. B., \& Einarsen, S. (2009). Interpersonal Problems Among Perpetrators and Targets of Workplace Bullying. Journal of Applied Social Psychology, 39, 1316-1333.

Glasø, L., Matthiesen, S. B., Nielsen, M. B., \& Einarsen, S. (2007). Do targets of bullying portray a general victim personality profile? Scandinavian Journal of Psychology, 48, 313-319.

Harvey, S. \& Keashley, L. (2003). Predicting the risk for aggression in the workplace: Risk factors, self-esteem and time at work. Social Behavior and Personality, 31, 807-814.

Hoel, H., Sparks, K., \& Cooper, C. L. (2001). The cost of violence/stress at work and the benefits of a violence/stress-free working environment. Geneva: International Labour Organization, 81.

Hofstede, G. (1984). Culture's consequences: International differences in workrelated values (Vol. 5). Sage publications.

Hofstede, G. (2001). Culture's consequences: Comparing values, behaviors, institutions and organizations across nations. Sage publications.

Hogh, A. \& Viitasara, E. (2005). A systematic review of longitudinal studies of nonfatal workplace violence. European journal of work and organizational psychology, 14(3), 291-313.

Hogh, A., Borg, V., \& Mikkelsen, K. L. (2003). Work-related violence as a predictor of fatigue: A 5-year follow-up of the Danish Work Environment Cohort Study. Work and Stress, 17, 182-194.

Kreiner, B., Sulyok, C., \& Rothenhäusler, H. B. (2008). Does mobbing cause post-traumatic stress disorder? Impact of coping and personality. Neuropsychiatry, 22(2), 112-23.

Lawoko, S., Soares, J. J. F. \&, Nolan, P. (2004). Violence towards psychiatric staff: a comparison of gender, job and environmental characteristics in England and Sweden. Work and Stress, 18(1), 39-55.

Leather, P., Lawrence, C., Beale, D., Cox, T., \& Dickson, R. (1998). Exposure to occupational violence and the buffering effects of intra-organizational support. Work and stress, 2, 161-178.

Lee, M., Kim, H., Shin, D., \& Lee, S. (2016). Reliability and validity of the workplace harassment questionnaire for Korean finance and service workers. Annals of Occupational and Environmental Medicine, 28(1), 45.

Leon-Perez, J. M., Notelaers, G., Arenas, A., Munduate, L., \&Medina, F. J. (2013). Identifying Victims of Workplace Bullying by Integrating Traditional Estimation Approaches Into a Latent Class Cluster Model. Journal of Interpersonal Violence, 20(10), 1-23. 
Leymann, H. (1996). The content and development of mobbing at work. European Journal of Work and Organizational Psychology, 5(2), 165-184.

Loh, J., Restubog, S. L. D., \& Zagenczyk, T. J. (2010). Consequences of workplace bullying on employee identification and satisfaction among Australians and Singaporeans. Journal of Cross-Cultural Psychology, 41, 236-252.

Lutgen-Sandvik, P., Tracy, S. J., \& Alberts, J. K. (2007). Burned by bullying in the American workplace: Prevalence, perception, degree, and impact. Journal of Management Studies, 44, 837-862.

Mikkelsen, E. G., Einarsen, S. (2001). Bullying in Danish work life: Prevalence and health correlates. European Journal of Work and Organizational Psychology, 10, 393-414.

Niedhammer, I., Chastang, J. F., \&David, S. (2008). Importance of psychosocial work factors on general health outcomes in the national French SUMER survey. Occupational Medicine, 58, 15-24.

Nielsen, M. B., Skogstad, A., Matthiesen, S. B., Glasø, L., Aasland, M. S., Notelaers, G., \& Einarsen, S. (2009). Prevalence of workplace bullying in Norway: Comparisons across time and estimation methods. European Journal of Work and Organizational Psychology, 18(1), 81-101.

Nielsen, M. B., Matthiesen, S., B., \& Einarsen, S. (2010). The impact of methodological moderators on prevalence rates of workplace bullying. A meta-analysis. Journal Of Occupational \& Organizational Psychology, 83(4), 955-979.

O'Connell, P. J., \& Williams, J. (2002). The incidence and correlates of workplace bullying in Ireland. Economic and Social Research Institute.

Ortega, A., Høgh, A., Pejtersen, J. H., \& Olsen, O. (2009). Prevalence of workplace bullying and risk groups: A representative population study. International Archives of Occupational and Environmental Health, 82(3), 417-426.

Paull, M., Omari, M., \& Standen, P. (2012). When is a bystander not a bystander? A typology of the roles of bystanders in workplace bullying. Asia Pacific Journal of Human Resources, 50(3), 351-366.

Parzefall, M. R., \& Salin, D. M. (2010). Perceptions of and reactions to workplace bullying: A social exchange perspective. Human relations, 63(6), 761-780.

Sourander, A., Ronning, J., Brunstein-Klomek, A., Gyllenberg, D., Kumpulainen, K., Niemelä, S., ... \& Moilanen, I. (2009). Childhood bullying behavior and later psychiatric hospital and psychopharmacologic treatment: findings from the Finnish 1981 birth cohort study. Archives of general psychiatry, 66(9), 1005-1012. 
Spector, P. E., Coulter, M. L., Stockwell, H. G., \& Matz, M. W. (2007). Perceived violence climate: A new construct and its relationship to workplace physical violence and verbal aggression, and their potential consequences. Work and Stress, 21, 117-130.

Tsuno, K., Kawakami, N., Inoue, A., \& Abe, K. (2010). Measuring workplace bullying: reliability and validity of the Japanese version of the Negative Acts Questionnaire. Journal of Occupational Health, 52(4), 216-226.

Viitasara, E., Sverke, M., \& Menckel, E. (2003). Multiple risk factors for violence to seven occupations groups in the Swedish caring sector. Industrial Relations, 58, 202-231.

Zapf, D., Einarsen, S., Hoel, H., \& Vartia, M. (2003). Empirical findings on bullying in the workplace. In S. Einarsen (Ed.). Bullying and Emotional Abuse in the Workplace: International Perspectives in Research and Practice, 103-126. London: Taylor and Francis. 


\section{Прашалник за негативно однесување на работно место \\ (NAQ - R)}

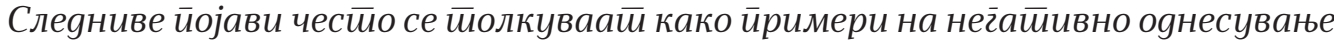

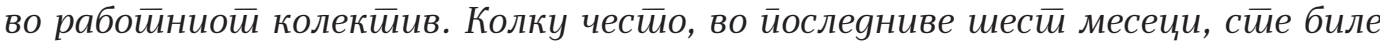
изложени на слеgниве нег̄айивни йојави?

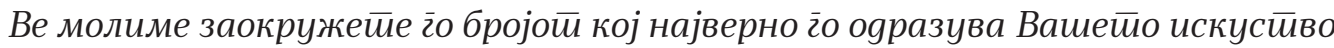
за йослеgниве 6 месеци:

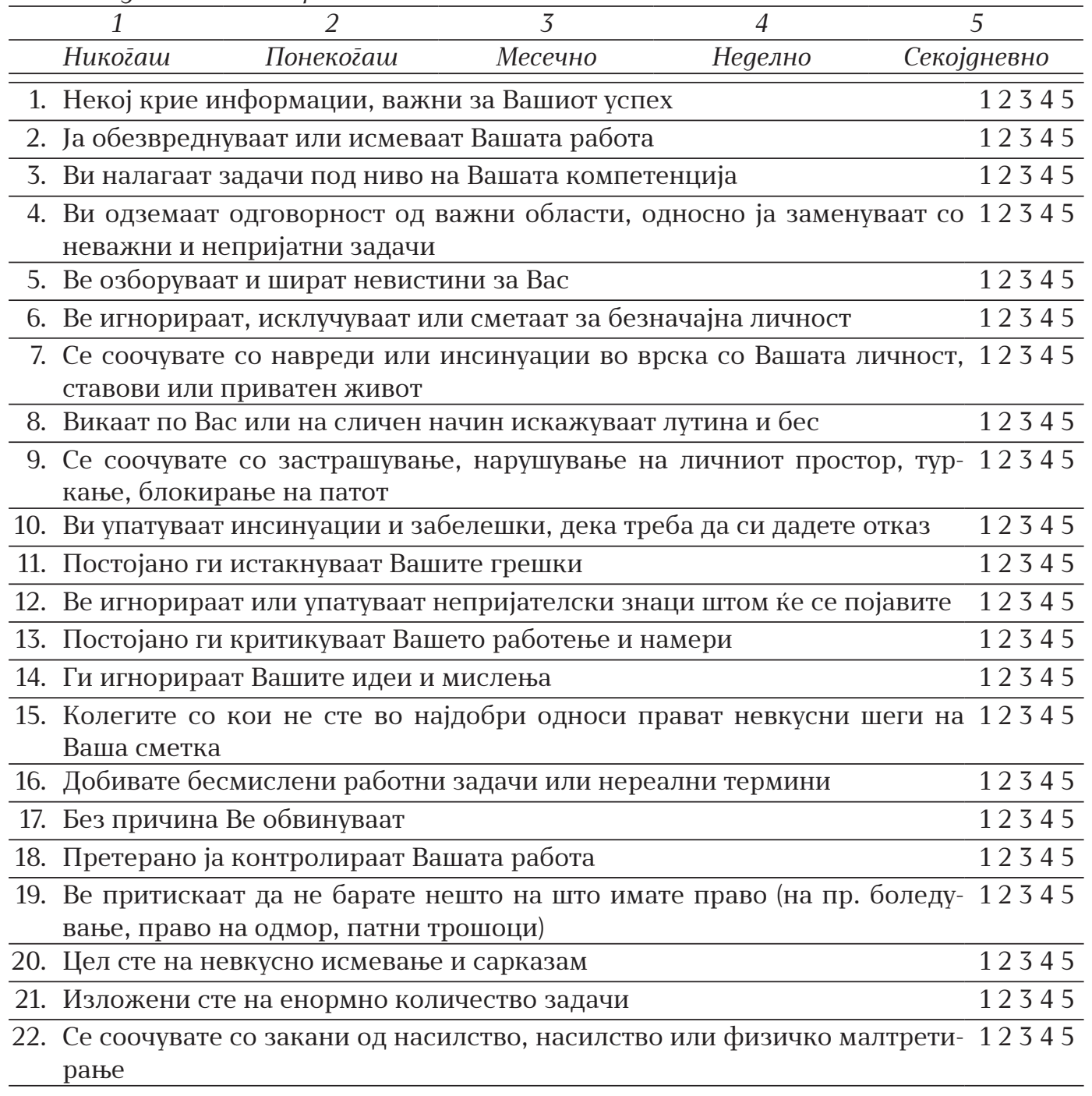

23. Дали некојӣай ве шиканирале на рабойа? Поg шикана йоgразбираме си-

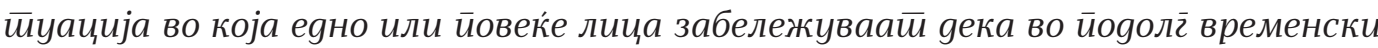
йериоg се изложени на нег̄айивно влијание оg сиирана на еgно или йовеќе gруг̄u 


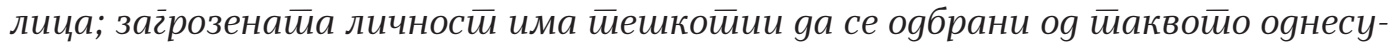
вање. Ваквиой осамен инцияенй не се смейа за шикана.

Ве молиме да означите, согласно со горната дефиниција, дали во последниве 6 месеци сте биле изложени на шиканирање на работното место?

$\mathrm{He}$

Да, ретко

Да, понекогаш

Да, неколку пати неделно

Да, секојдневно

NAQ - Negative Acts Questionnaire

(C) Einarsen, Raknes, Matthiesen og Hellesøy, 1994; Hoel, 1999

Translation: Panajotis Cakirpaloglu

Слика 1: Прашалник за негативно однесување на работно место (NAQ - R) 


\title{
PSYCHOLOGICAL REVIEW ON BULLYING AT WORKPLACE:
} APPEARANCE, FACTORS AND MEASUREMENT

\author{
Panajotis Cakirpaloglu \\ Simona Dobešová Cakirpaloglu \\ Jan Šmahaj \\ Martin Zielina
}

\begin{abstract}
The psychological interest in workplace bullying which has lasted for more than two decades indicates that there are different estimates of the prevalence rate of this phenomenon, i.e. that such differences are not only due to the methodological reasons but include a number of personal, organizational and cultural specifics. What empirical studies agree on is that long-term workplace bullying regularly causes various psychological and other complications faced by the victimized employee. The purpose of this article is an expert presentation of the psychological definitions and the factors of workplace bullying with a review of the methodological issues related to measuring victimization in the work collective. Special emphasis is placed on the problem of differentiating specific types of workplace bullying by applying behavioural and subjective indicators of the victimization. The Czech version of the revised Negative Acts Questionnaire (NAQ-R) was used to measure the workplace bullying. The results of the survey conducted on 7103 employees in the state, private and non-governmental collectives in the Czech Republic showed that the general estimate of bullied persons is between $14.84 \%$ and $24.78 \%$. The criteria of behavioural indicators and perceived victimization offer a deeper insight into the workplace bullying structure, whereby the data of 7103 surveyed employees are differentiated into $81.75 \%$ non-bullied and $18.28 \%$ victimized individuals. By crossing the two criteria, the most critical group of $7.79 \%$ bullied persons was determined with awareness of their own victimization as well as the empirical confirmation of the workplace bullying.
\end{abstract}

Keywords: workplace bullying, NAQ-R, prevalence, victimizatio 